\title{
Effect of the summer monsoon on aerosols at two measurement stations in Northern India - Part 1: PM and BC concentrations
}

\author{
A.-P. Hyvärinen ${ }^{1}$, T. Raatikainen ${ }^{1, *}$, D. Brus ${ }^{1,2}$, M. Komppula ${ }^{3}$, T. S. Panwar ${ }^{4}$, R. K. Hooda ${ }^{4}$, V. P. Sharma ${ }^{4}$, and \\ H. Lihavainen ${ }^{1}$ \\ ${ }^{1}$ Finnish Meteorological Institute, Erik Palménin aukio 1, P.O. Box 503, 00101, Helsinki, Finland \\ ${ }^{2}$ Laboratory of Aerosol Chemistry and Physics, Institute of Chemical Process Fundamentals Academy of Sciences of the \\ Czech Republic, Rozvojová 135, 16502 Prague 6, Czech Republic \\ ${ }^{3}$ Finnish Meteorological Institute, Yliopistonranta 1F, P.O. Box 1627, 70211 Kuopio, Finland \\ ${ }^{4}$ The Energy and Resources Institute (TERI), Darbari Seth Block, IHC Complex, Lodhi Road, New Delhi 110 003, India \\ * currently at: School of Earth \& Atmospheric Sciences, Georgia Institute of Technology, 311 Ferst Drive, Atlanta, GA \\ 30332-0340, USA
}

Received: 21 December 2010 - Published in Atmos. Chem. Phys. Discuss.: 19 January 2011

Revised: 30 June 2011 - Accepted: 10 July 2011 - Published: 15 August 2011

\begin{abstract}
Particulate matter (PM) and equivalent black carbon (BCe) concentrations were measured at two locations in northern India during 2006-2010. The first measurement station was a background site in Mukteshwar, about $350 \mathrm{~km}$ northeast of New Delhi, in the foothills of the Indian Himalayas. The second measurement site was located in Gual Pahari, about $25 \mathrm{~km}$ south of New Delhi. Here we focused on resolving the effects of the Indian summer monsoon on the particulate matter and equivalent black carbon concentrations at two stations. The average monsoon time concentrations were decreased by 55-70\% compared to the premonsoon average concentrations at both stations, decreasing as a function of the total local rainfall during the monsoon season. In Mukteshwar during the monsoon, the $24 \mathrm{~h} \mathrm{PM} 2.5$ concentrations were nearly always below the Indian National Air Quality Standard of $60 \mu \mathrm{g} \mathrm{m}^{-3}$. In Gual Pahari, $13 \%$ of days exceeded this level during the monsoon season. However, the $24 \mathrm{~h}$ guideline of $25 \mu \mathrm{g} \mathrm{m}^{-3}$ given by the World Health Organization was more difficult to meet. In addition to loss processes, aerosol concentrations during the early monsoon were found to be affected by primary emissions, most likely from dust events from the Thar Desert. This resulted in elevated fractions of the coarse mode, $\mathrm{PM}_{2.5-10}$ at both stations. In Mukteshwar, additional dust contribution came from east of the station, from the Himalayan region. We also determined the characteristic transition times be-
\end{abstract}

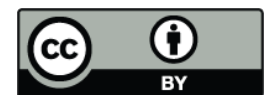

Correspondence to: A.-P. Hyvärinen (antti.hyvarinen@fmi.fi) tween the pre-monsoon, monsoon and post-monsoon. The onset and withdrawal transitions occurred faster in Mukteshwar than in Gual Pahari, both being typically less than 10 days. Transition periods in Gual Pahari took between 17 and 31 days. The shorter transition times in Mukteshwar were probably related to the more intense rains due to the mountain location, and the fact that the station was most of the time in the free troposphere.

\section{Introduction}

Over $60 \%$ of the world's population is dependent on the water brought by the Asian Summer Monsoon. In addition to being a water supply and providing agricultural irrigation, the monsoon brings relief to the severe pollution built up during winter and spring in the area. The largest and most persistent of these pollution hazes, called the "brown cloud", covers an area of about 10 million $\mathrm{km}^{2}$ over Southern Asia (e.g. Lelieveld et al., 2001; Nakajima et al., 2007; Ramanathan et al., 2007). This particulate air pollution is assumed to originate from fossil fuel and biomass burning. Especially in mega-cities such as New Delhi, air pollution is a major health issue, causing as much as 3500 excess cases of cardiovascular mortality (Gurjar et al., 2010) per year. Even in the remote Himalayan areas, spring time particulate matter concentrations exceed the standard values set by the WHO (Panwar et al., 2011). During monsoon, the pollutants are brought down in different wet deposition processes. These reasons provide a comprehensive motivation to quantify the

Published by Copernicus Publications on behalf of the European Geosciences Union. 
effect of the monsoon on aerosols in the area. In addition, it's well known that aerosols can modulate the monsoon and thus the whole water cycle (Lau and Kim, 2006; Bollasina et al., 2008; Meehl et al., 2008).

The Finnish Meteorological Institute (FMI) in cooperation with the Energy and Resources Institute of India (TERI) have established two well-equipped aerosol measurement stations in Northern India. One station was located at Gual Pahari from December 2007 to January 2010. The site represented urban background in the Indo-Gangetic plains close to New Delhi (Hyvärinen et al., 2010). Mukteshwar, on the other hand, is a relatively clean site at the foothills of the Himalayas about $270 \mathrm{~km}$ NE from Gual Pahari and about $2 \mathrm{~km}$ above the plains (Hyvärinen et al., 2009; Komppula et al., 2009). The Mukteshwar station has been operational since September 2005.

In this paper, we focus on investigating the particulate matter and equivalent black carbon and their development during the Summer Monsoon seasons at the two stations. We quantify the effect that the monsoon has on the aerosol concentrations and compare the differences between different years at the two locations. Furthermore, we attempt to determine the characteristic times of the onset and withdrawal of monsoon. From the health perspective, it's interesting to know how quickly the concentrations change between the pre-monsoon, monsoon, and post-monsoon seasons. In the companion paper of this manuscript, we focus on the effect of monsoon on aerosol physical and optical properties (Hyvärinen et al., 2011).

\section{Measurement sites and methods}

\subsection{Measurement locations}

The first measurement station was a background site in Mukteshwar $\left(29^{\circ} 26^{\prime} \mathrm{N}, 79^{\circ} 37^{\prime} \mathrm{E}\right.$, Fig. 1), about $350 \mathrm{~km}$ northeast of New Delhi in India. The site was located at $2180 \mathrm{~m}$ above sea level in a rural region in the Himalaya Mountains. The station was surrounded by an agricultural test field. No major local pollution sources were known to affect the site. The nearest towns, Nainital and Almora, are located $25 \mathrm{~km}$ to the west and north of the site, respectively (see Hyvärinen et al. (2009) for a more detailed site description). Since the location was a remote place with minimal local emissions, we believe that the site represents, to the extent possible, a regional background in India. The second measurement site (Fig. 1) was located in Gual Pahari $\left(28.43^{\circ}\right.$ North, $77.15^{\circ}$ East, $243 \mathrm{~m}$ a.s.1.), Gurgaon, about $25 \mathrm{~km}$ south of New Delhi (see Hyvärinen et al. (2009) for a more detailed site description). The surroundings represent a semi-urban environment. Distance between the stations is about $270 \mathrm{~km}$. The presented results cover the years from 2006 to 2009 for Mukteshwar and from 2008 to 2009 for Gual Pahari.

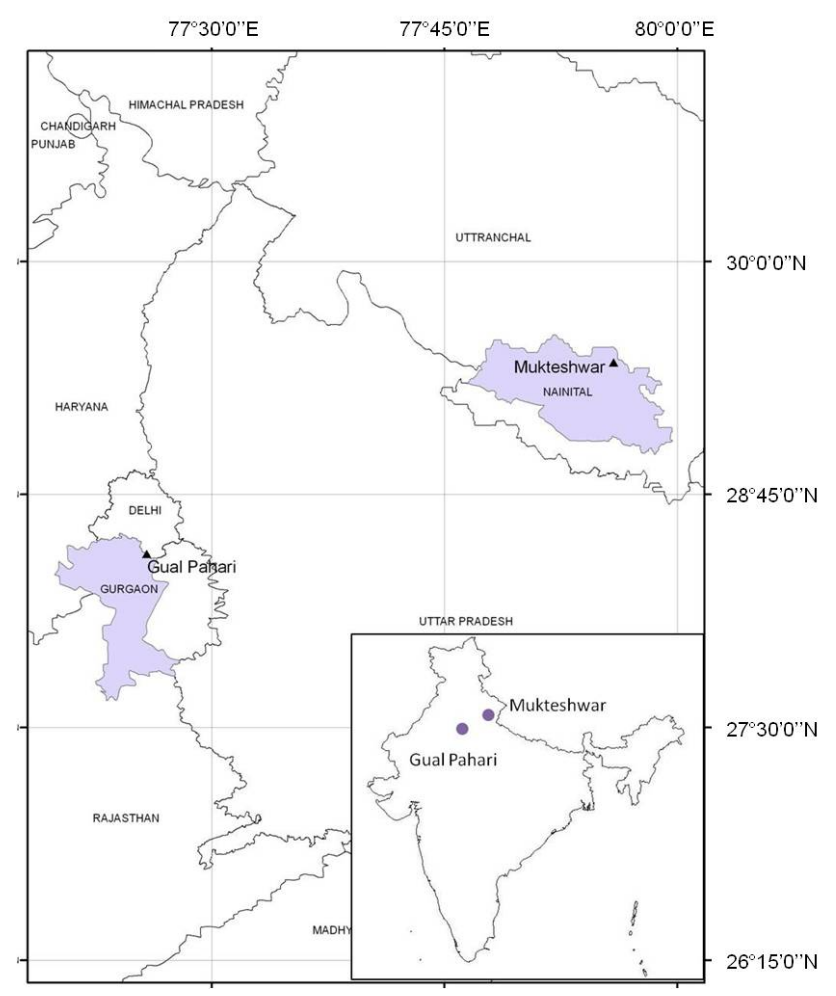

Fig. 1. Locations of the Gual Pahari and Mukteshwar measurement stations.

\subsection{Instruments}

In Mukteshwar, the $\mathrm{PM}_{10}$ and $\mathrm{PM}_{2.5}$ measurements were carried out using real-time beta attenuation particulate monitors (FH 62 I-R) manufactured by Thermo Scientific. The equivalent black carbon concentrations were measured with a Magee AE 31 Aethalometer. In addition, other measurements included the particle number size distribution from $10 \mathrm{~nm}$ to $800 \mathrm{~nm}$, aerosol scattering coefficient, and meteorological parameters including temperature, pressure, relative humidity and wind speed/direction. The measurements and instruments at the site are presented in more detail by Hyvärinen et al. (2009) and Komppula et al. (2009). The equivalent black carbon concentrations were sampled from a $\mathrm{PM}_{2.5}$ inlet.

In Gual Pahari, $\mathrm{PM}_{2.5}$ and $\mathrm{PM}_{10}$ were measured with a Thermo Scientific SHARP Monitors model 5030, which utilizes a hybrid method of beta attenuation with light scattering. Aerosol equivalent black carbon was measured with a Thermo Scientific Multi-Angle Absorption Photometer, MAAP from a $\mathrm{PM}_{10}$ inlet. In addition, basic weather parameters were measured. A more detailed presentation can be found in Hyvärinen et al. (2010). 


\subsection{Data processing}

The measured data was saved as five minute averages. The five minute data was checked with outliers and obvious instrument malfunctions periods removed. The data was then averaged to one hour with the condition that each hour had more than 25 min of data. All longer time averages were calculated from the hourly data, which was also converted to STP-conditions. It has to be noted that regulatory guidelines set by WHO are from ambient measurements, not in STP conditions. We will mention specifically, whether our concentrations are presented in ambient or STP conditions. One month averages were only calculated if the data covered more than $30 \%$ of the time. For seasonal analyses, the year was divided into four seasons: winter (DecemberFebruary), pre-monsoon (March-onset of monsoon), monsoon season and post-monsoon (withdrawal of monsoonNovember). When seasonal averages were calculated, the determined onset and withdrawal dates defined the monsoon season for each year separately. While these dates were typically available for New Delhi, the dates for Mukteshwar had to be estimated (see Raatikainen et al., 2011), and may contain some inaccuracy. Again a $30 \%$ data coverage level was demanded.

Backward trajectories were calculated for every three hours with the FLEXTRA model (Stohl et al., 1995) for the 950-hPa pressure level for Gual Pahari and 750-hPa pressure level for Mukteshwar. For further trajectory analysis, the surroundings were split into 30 degree sectors to enable a more detailed investigation of the source areas of particulate pollution. For each trajectory, a number of quantities were calculated, including the sectors in which the air was 24,72 and $120 \mathrm{~h}$ prior to its arrival at the measurement sites, the fraction of time the air had spent in each sector, average heights above sea level and above ground level. Taken together, these quantities provide the basis for distinguishing between different air masses and their influences on measured aerosol properties.

\section{Results}

\subsection{Monsoon characteristics}

The inter-annual characteristics of the monsoon season in Mukteshwar and Gual Pahari are presented in Table 1 and Fig. 2. District-wise monthly rainfall data from the India Meteorological Department (IMD) web pages (http://www.imd. gov.in) was used. Rainfall in Mukteshwar was calculated as an average of that at Nainital and Almora, which are the two closest measurement stations, $25 \mathrm{~km}$ to the west and north, respectively. Similarly, Gual Pahari rainfall was an average of that at the Gurgaon, Faridabad and New Delhi stations. During the four measurement years there were contrasting monsoon seasons, with both excessive rain and drought. Not

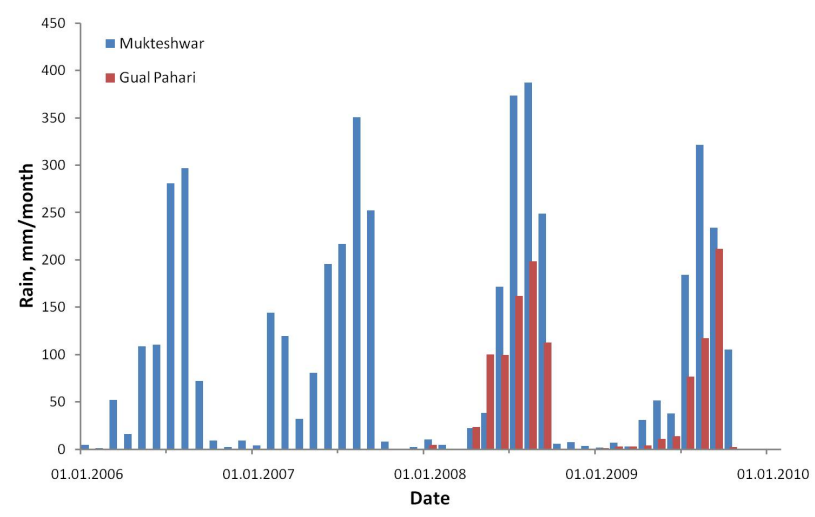

Fig. 2. Monthly rain accumulation during running of the measurement stations.

surprisingly, heavier rainfall was observed in Mukteshwar, as air masses flowing uphill are more likely to form rain. In our measurement locations, the year 2008 exhibited the most rainfall, with a total of $1181 \mathrm{~mm}$ in the Mukteshwar area and $570 \mathrm{~mm}$ in Gual Pahari. The year 2008 also exhibited an early monsoon onset date of 16.6., which is one of the earliest onset dates recorded in the area with rainfall data available since 1901 (Tyagi et al., 2009). The weakest monsoon occurred in 2006, with $760 \mathrm{~mm}$ total rain in Mukteshwar. This was similar to 2009, when $780 \mathrm{~mm}$ rained in Mukteshwar and $420 \mathrm{~mm}$ in Gual Pahari. Interestingly, in Mukteshwar during 2009 a considerable amount of rainfall was received in October, after the monsoon had officially withdrawn.

General weather parameters and backward trajectories have been presented in detail in our previous papers (Hyvärinen et al. 2009, 2010; Komppula et al., 2009; Raatikainen et al., 2011); and only a short summary concerning the monsoon season is presented here. The monsoon seasons at both locations were characterized by low pressures: $781 \mathrm{hPa}$ and $973 \mathrm{hPa}$ in Mukteshwar and Gual Pahari, respectively; and high RH's: $88 \%$, and $74 \%$. The average temperature in Mukteshwar was $17.7^{\circ} \mathrm{C}$ and in Gual Pahari $28.0^{\circ} \mathrm{C}$. The diurnal variation of these parameters was weaker than during other times of the year. The trajectories had a distinct pattern during the monsoon season. In Mukteshwar, the most common sector was from 90 to $180^{\circ}$, i.e. from the Bay of Bengal, with about $47 \%$ contribution. The sector from 210 to $270^{\circ}$ (Arabian Sea) contributed an additional $22 \%$. In Gual Pahari, the prominent sectors were nearly similar from $210-270^{\circ}$ and $90-120^{\circ}$, but here a $43 \%$ contribution was obtained from the Arabian Sea and $23 \%$ from the Bay of Bengal. Inter-annual variations of the trajectories were also studied, but no significant differences were found. Outside the monsoon season, westerly air masses dominated.

In previous studies (Raatikainen et al., 2011), the boundary layer height was indicated to be the main reason for the different annual and diurnal variation of aerosol properties at these two stations. The explanation was based on mixing 
Table 1. Onset/withdrawal dates of monsoon in Mukteshwar and Gual Pahari. Total rainfall during the monsoon period, calculated from monthly data between June-September.

\begin{tabular}{c|cc|c|cc}
\hline & \multicolumn{2}{|c|}{ Onset } & Withdrawal & \multicolumn{2}{c}{ Rainfall (mm) } \\
\hline & Mukteshwar & Gual Pahari & Both & Mukteshwar & Gual Pahari \\
\hline 2006 & $30.6 .^{1}$ & $30.6 .^{1}$ & $27.9 .{ }^{1}$ & 760 & 341 \\
2007 & $18.6 .^{1}$ & $30.6{ }^{1}$ & $2.10 .{ }^{1}$ & 1015 & 424 \\
2008 & $16.6^{2}$ & $16.6 .^{2}$ & $28.9 .^{2}$ & 1181 & 573 \\
2009 & $29.6^{3}$ & $30.6 .^{3}$ & $28.9 .^{3}$ & 780 & 420 \\
\hline
\end{tabular}

${ }^{1}$ http://www.imd.gov.in/section/nhac/dynamic/Monsoon_frame.htm; ${ }^{2}$ Tyagi et al. (2009); ${ }^{3}$ Tyagi et al. (2010).

of the cleaner air masses at the altitude of Mukteshwar with polluted air masses from the plains below. This occurred when the boundary layer height was elevated above the Mukteshwar altitude (2180 m a.s.1.). During the monsoon season, the average maximum boundary layer heights did not exceed $1500 \mathrm{~m}$ (Fig. 3), so Mukteshwar resided mostly in the free troposphere.

\subsection{General features}

The summer monsoon provides the main removal mechanism for atmospheric pollutants in the Indian subcontinent by different wet deposition processes. These include removal by falling rain drops in both locations, and in Mukteshwar, cloud processing by mountain fogs and clouds caused by rising air masses. The annual variation of $\mathrm{PM}_{2.5}$ for both stations in 2008 can be seen in Fig. 4. At the end of the dry season, before the monsoon, the concentrations were close to the annual maxima, especially in Mukteshwar. This can be attributed dust events which occur when air masses arrive from the desert areas close to the Arabian Sea, such as the Thar Desert (Gautam et al., 2009). The effect of the summer monsoon is very clear in this figure. When the rain accumulation increased in June-September, the $\mathrm{PM}_{2.5}$ concentration decreased drastically. It is important to notice from the health perspective that the monsoon season was one of the only times of the year when $\mathrm{PM}_{2.5}$ were mostly below the national $24 \mathrm{~h}$ ambient air quality standard level of $60 \mu \mathrm{g} \mathrm{m}$ (Central Pollution Control Board of India, 2009) at both measurement locations. However, the air quality guidelines given by the WHO $\left(\mathrm{PM}_{2.5}<25 \mu \mathrm{g} \mathrm{m}^{-3}\right)$ were still often exceeded.

The average monsoon aerosol concentrations decreased by about $50-70 \%$ compared to the pre-monsoon average concentrations at both stations (Table 2, Fig. 5), decreasing as a function of the total rainfall during the monsoon season. The most effective decrease of aerosol concentrations was observed during 2008 in Mukteshwar. During 2008 the rain amounts were the highest of the study period as well. The relative decrease can be estimated from the rain accumulation alone by an accuracy of $\pm 5 \%$. The measured aerosol property and measurement location affected the concentra-
Table 2. Difference between the pre-monsoon and monsoon season aerosol concentrations in Mukteshwar and Gual Pahari. Concentrations are in STP conditions.

\begin{tabular}{lrrr}
\hline Year & $\begin{array}{r}\mathrm{BCe} \\
\mu \mathrm{g} \mathrm{m}^{-3}\end{array}$ & $\begin{array}{r}\mathrm{PM}_{2.5} \\
\mu \mathrm{g} \mathrm{m}^{-3}\end{array}$ & $\begin{array}{r}\mathrm{PM}_{10} \\
\mu \mathrm{g} \mathrm{m}^{-3}\end{array}$ \\
\hline Mukteshwar & & & \\
\hline 2006 Pre/Mons & $1.55 / 0.55$ & $52.8 / 21.2$ & $103.7 / 48.3$ \\
$\%$ diff & -64.6 & -60.0 & -53.4 \\
2007 Pre/Mons & $1.83 / 0.68$ & - & - \\
$\%$ diff & -62.9 & - & - \\
2008 Pre/Mons & $1.79 / 0.53$ & $65.7 / 21.4$ & 133.1 \\
$\%$ diff & -70.4 & -67.5 & - \\
2009 Pre/Mons & $1.76 /-$ & $73.6 / 31.8$ & $117.0 / 48.7$ \\
$\%$ diff & - & -56.8 & -58.4 \\
\hline Gual Pahari & & & \\
\hline 2008 Pre/Mons & $9.47 /-$ & $99.8 / 42.3$ & $186.5 / 93.1$ \\
$\%$ diff & - & -57.7 & -50.1 \\
2009 Pre/Mons & $9.07 / 4.11$ & $119.1 / 48.3$ & $203.9 / 88.4$ \\
$\%$ diff & -54.6 & -59.5 & -56.6 \\
\hline
\end{tabular}

tion decrease fine structure, showing a more effective decrease for equivalent black carbon and a less effective decrease for $\mathrm{PM}_{10}$ in Mukteshwar but vice versa in Gual Pahari. The more effective decrease of BCe in Mukteshwar may be explained by the additional cloud removal process. Aged BC particles are typically hygroscopic, which further enhances activation into cloud droplets. Data from the rainiest years was not available for $\mathrm{PM}_{10}$, which explains the low $R^{2}$ value shown in Fig. 5.

The amount of rainfall dictated the general magnitude of the aerosol decrease, but in addition to the loss processes, the concentrations were of course dependent on the sources. An example of this was seen in Gual Pahari. While both 2008 and 2009 showed very similar decreases in the PM concentrations due to similar rainfalls, the decrease was slightly stronger during 2009 , even though this was a weaker 


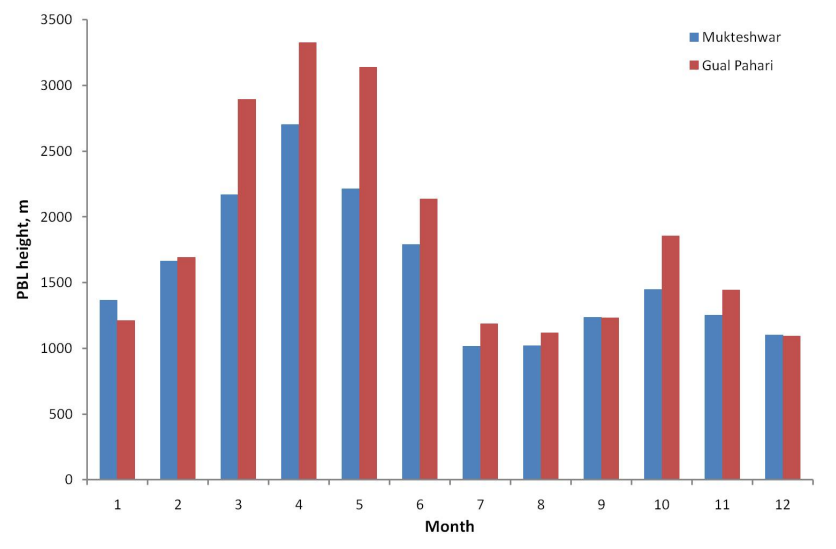

Fig. 3. Annual variation for the averaged daily maximum boundary layer heights (PBL) obtained from the European Centre for Medium-Range Weather Forecasts (ECMWF).

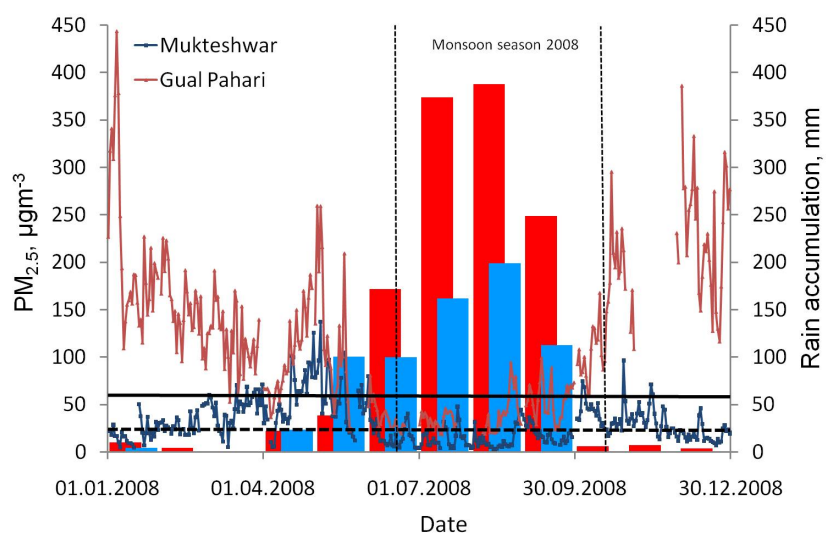

Fig. 4. $\mathrm{PM}_{2.5}$ and rain accumulation at Mukteshwar and Gual Pahari during 2008. Solid lines denote daily $24 \mathrm{~h}$ PM concentrations, dotted lines monthly rain accumulation. The black line is the Indian national $24 \mathrm{~h}$ ambient air quality $\mathrm{PM}_{2.5}$ standard of $60 \mu \mathrm{g} \mathrm{m}^{-3}$, the dotted line the corresponding WHO guideline of $25 \mu \mathrm{g} \mathrm{m}^{-3}$. Concentrations are in ambient conditions.

monsoon year. This was due to sources. In 2008 there were more episodic high concentrations observed during the monsoon, and these increased the average concentrations. It has to be noted however that the deviations in the source strength were only able to affect the fine structure of the seasonal concentrations, and the magnitude was still governed by the rainfall observed during the monsoon. Pre-monsoon and early monsoon is the dust season in India (e.g. Dey and Tripathi, 2008; Gautam et al., 2009, 2011; Ram et al., 2008, 2010). The prospect of the high concentrations during monsoon being mineral dust is discussed in Sect. 3.5. The fine structure in the BCe concentration may also depend on sources. The Gual Pahari location close to New Delhi makes it more susceptible to vehicular BC emissions, which in part may explain the less effective decrease there during the monsoon.

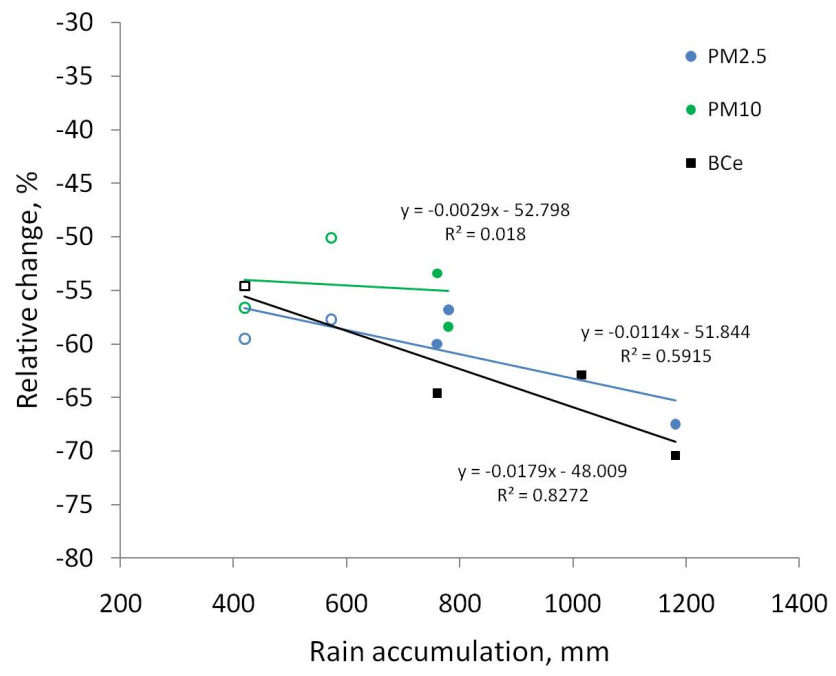

Fig. 5. The relative change of the aerosol mass concentrations from the pre-monsoon to monsoon season as a function of the JuneSeptember rain accumulation. Solid symbols: data from Mukteshwar; open symbols: data from Gual Pahari.

\subsection{Aerosols at monsoon onset and withdrawal}

The transient periods between pre-monsoon/monsoon and monsoon/post-monsoon seasons provide a possibility to look at the characteristic times of aerosol removal and build-up. This information is interesting from the health perspective, to have an idea how fast the concentrations will decrease below the air quality standard levels at the onset and increase again to harmful levels at the withdrawal (see Sect. 3.6). Another motivation is to understand the main mechanisms driving the concentration changes.

We determined these characteristic times by examining all the mass concentration data $\left(\mathrm{PM}_{10}, \mathrm{PM}_{2.5}, \mathrm{BCe}\right)$. Data was first normalized to the mean value of the concentrations during each monsoon season. Normalized data was then averaged as a single proxy describing the concentrations as $24 \mathrm{~h}$ averages. The transient time was determined as the time it took for the proxy to decrease from the pre-monsoon average to the monsoon average or increase from the monsoon average to the post-monsoon average. To make sure that these average values reflected the true end and beginning of the seasons, a further criterion was that the $24 \mathrm{~h}$ average had to be within the $25-75$ percentile values of the prevailing season for at least 5 consecutive days before and after the transient period. As these choices are somewhat subjective, the presented characteristic transition times are only qualitative.

The onset transition in Gual Pahari took about 20 to 30 days, and began typically during the late pre-monsoon season (Table 3, Fig. 6). From the rain accumulation data we were able to conclude that the beginning of the transient period in 2008 coincided with the first heavy rain showers, and there was over $130 \mathrm{~mm}$ of rainfall in the area during the transition 

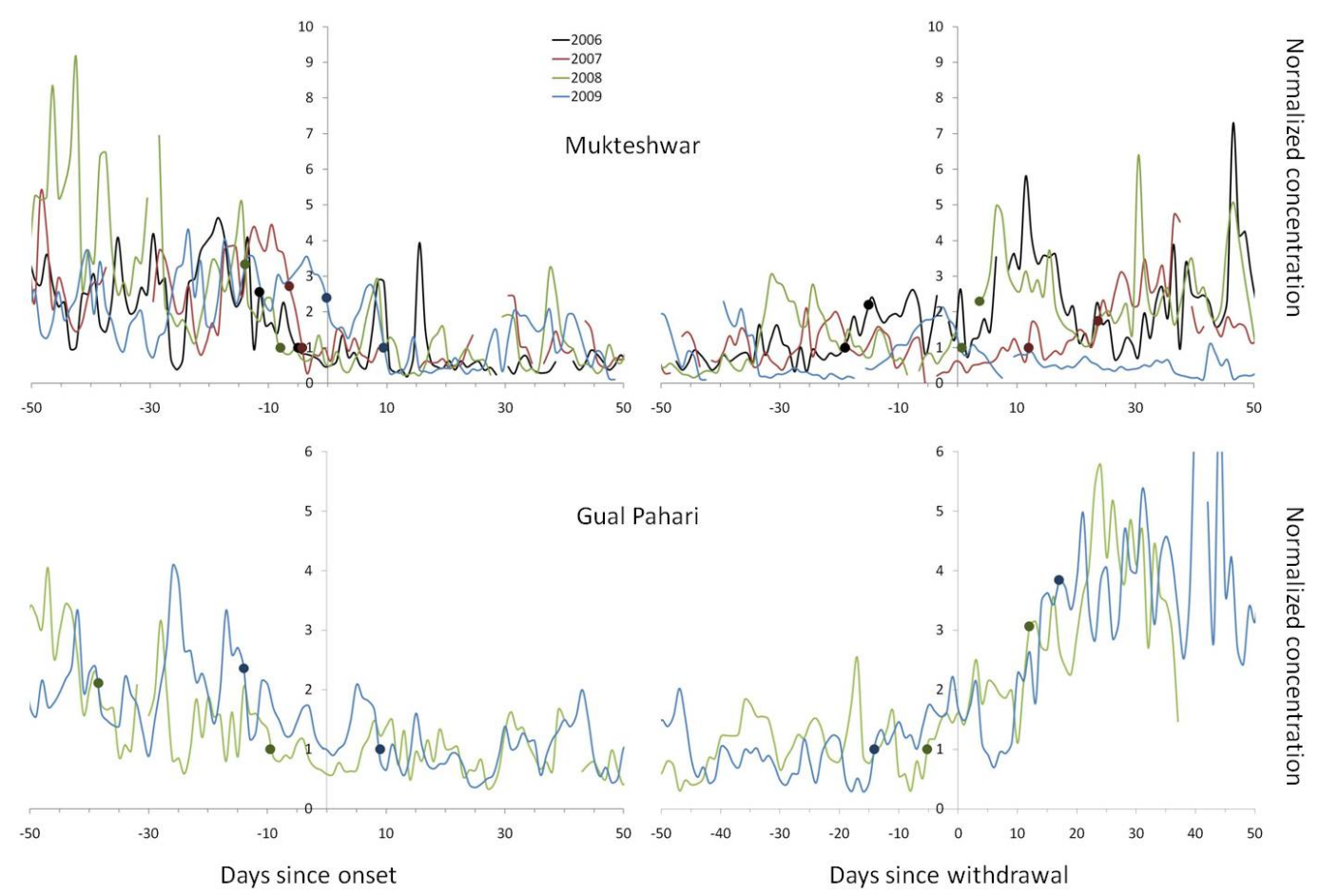

Fig. 6. Transient periods between the pre-monsoon/monsoon and monsoon/post-monsoon season at Mukteshwar and Gual Pahari. Relative concentrations are 24-h averages of normalized $\mathrm{PM}_{2.5}, \mathrm{PM}_{10}$ and $\mathrm{BCe}$ concentrations with annual monsoon means set to unity for each property. Dots mark the beginning and ending of the transient periods. See text for details.

Table 3. Characteristic transition times for the monsoon season onset and withdrawal according to aerosol concentration changes. See text for details.

\begin{tabular}{rrrrr}
\hline & $\begin{array}{r}\text { Mukteshwar } \\
\text { onset }\end{array}$ & $\begin{array}{r}\text { Mukteshwar } \\
\text { withdrawal }\end{array}$ & $\begin{array}{r}\text { Gual Pahari } \\
\text { onset }\end{array}$ & $\begin{array}{r}\text { Gual Pahari } \\
\text { withdrawal }\end{array}$ \\
\hline 2006 & $6.5 \mathrm{~d}$ & $4 \mathrm{~d}$ & - & - \\
2007 & $2 \mathrm{~d}$ & $12 \mathrm{~d}$ & - & - \\
2008 & $6 \mathrm{~d}$ & $3 \mathrm{~d}$ & $29 \mathrm{~d}$ & $17 \mathrm{~d}$ \\
2009 & $9.5 \mathrm{~d}$ & - & $23 \mathrm{~d}$ & $31 \mathrm{~d}$ \\
\hline
\end{tabular}

d = days

period. This resulted in an early beginning of the transition which was nearly 30 days long. In 2009, basically no local rain $(10 \mathrm{~mm})$ was observed in Gual Pahari during the transition period. However, the transient period still took over 20 days, which suggest that in general the local rains - which could lower the concentrations temporarily - were not the main driving force behind the initial concentration change in Gual Pahari. The transition onset period was much shorter in Mukteshwar, lasting from about 2 to 10 days (Table 3). In Mukteshwar, the rain amounts were high already in June, which suggests that the aerosol there was brought down by efficient wet deposition. Unfortunately no local rain data was available from Mukteshwar, so we cannot conclude if this was the reason for the shorter transition period. In addition to the wet deposition processes, it's likely that the transport patterns of aerosols had a role in the change in concentrations.

The withdrawal of monsoon and consequent increase of the aerosol concentrations also differed clearly at the two stations. In Mukteshwar, the transition period varied from about 3 to 10 days, while in Gual Pahari, the transient period took up to 31 days (Table 3, Fig. 6). Again this illustrates that the build-up process was different at the two locations. In Mukteshwar, the post-monsoon concentrations and size distributions (See Hyvärinen et al., 2011) were close to the monsoon period averages. Thus, the post-monsoon average concentrations were achieved quickly. In fact, in 2009 the postmonsoon concentrations were even lower than the monsoon concentrations, partly due to additional rains during October (Fig. 2). In Gual Pahari, the post-monsoon averages were almost 3 times as high as the monsoon season averages. During post-monsoon, the fine mode began to dominate (see Fig. 9), and the build-up process of this fine mode from secondary sources took a longer time. 


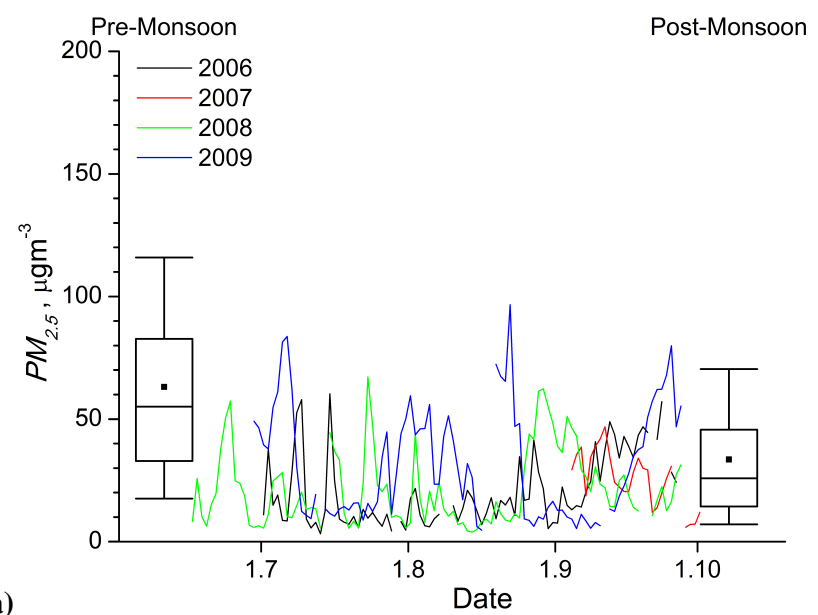

(a)

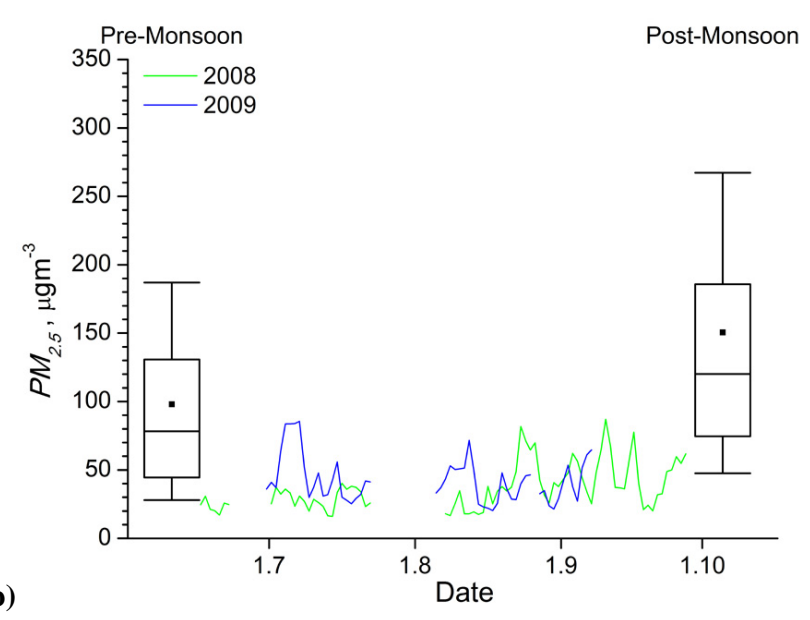

Fig. 7. $\mathrm{PM}_{2.5}$ mass. (a) Mukteshwar (b) Gual Pahari. Lines are $24 \mathrm{~h}$ running averages from the monsoon season, box plots denote the pre- and post-monsoon seasonal values of $10 \%$-ile, $25 \%$-ile, median (line), average (dot), $75 \%$-ile, and $90 \%$-ile. Concentrations are in STP conditions.

\subsection{Mass distribution and equivalent black carbon}

The variation of $\mathrm{PM}_{2.5}$ and $\mathrm{PM}_{10}$ concentrations can be seen in Figs. 7 and 8. In Mukteshwar, the monsoon season average value of $\mathrm{PM}_{2.5} / \mathrm{PM}_{10}$ was 0.69 , indicating dominance of fine particles (Fig. 9). However, episodic values down to 0.2 were encountered. In Gual Pahari the $\mathrm{PM}_{2.5} / \mathrm{PM}_{10}$ fractions were typically lower, with the monsoon season average of 0.53 , indicating a stronger coarse mode contribution than in Mukteshwar. Especially in 2008, episodic values down to 0.2 were observed. The high contributions from the coarse mode in Gual Pahari were related to the break spells of the monsoon. Aerosols from primary sources have a potential to increase quickly, whereas for the fine fraction, the build up process needs more time as the secondary particles have to grow to have a noteworthy mass. The origin of these episodic high coarse mode concentrations are studied in the next section.
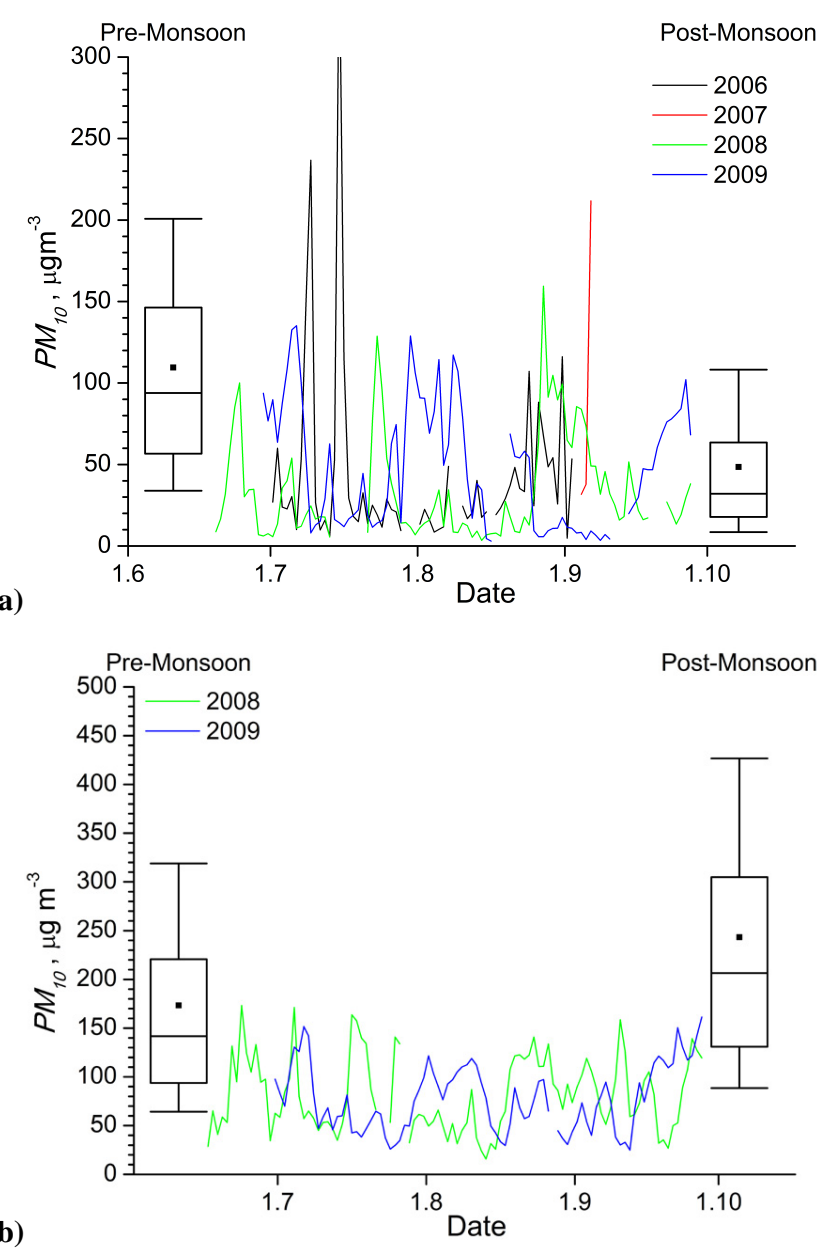

Fig. 8. $\mathrm{PM}_{10}$ mass. (a) Mukteshwar (b) Gual Pahari. Lines are $24 \mathrm{~h}$ running averages from the monsoon season, box plots denote the pre- and post-monsoon seasonal values of $10 \%$-ile, $25 \%$-ile, median (line), average (dot), $75 \%$-ile, and $90 \%$-ile. Concentrations are in STP conditions.

The fraction of equivalent black carbon (BCe) in $\mathrm{PM}_{2.5}$ mass increased very slightly from the pre-monsoon during the early monsoon period (Fig. 10). In Mukteshwar, the monsoon season average $\mathrm{BCe} / \mathrm{PM}_{2.5}$ ratio (calculated from hourly averages) was $4.3 \%$, while the pre-monsoon value was $3.3 \%$. In practice this change is insignificant, and as noted in Fig. 5, if the $\mathrm{BCe} / \mathrm{PM}_{2.5}$ ratio was calculated from seasonal averages, it would have actually increased. This implies that the wet deposition processes removed particles with different chemistry and hygroscopicity with only little differences in Mukteshwar, or that the aerosol inclined to be internally mixed. For Gual Pahari, data coverage does not allow us to present the full season average for monsoon. However, for July the ratio $\mathrm{BCe} / \mathrm{PM}_{2.5}$ was $13.5 \%$, while the premonsoon average was $9.4 \%$. The close proximity to New Delhi may in part explain the higher $\mathrm{BCe} / \mathrm{PM}_{2.5}$ during there during the monsoon, or BCe may have been less effectively removed than other particles. 


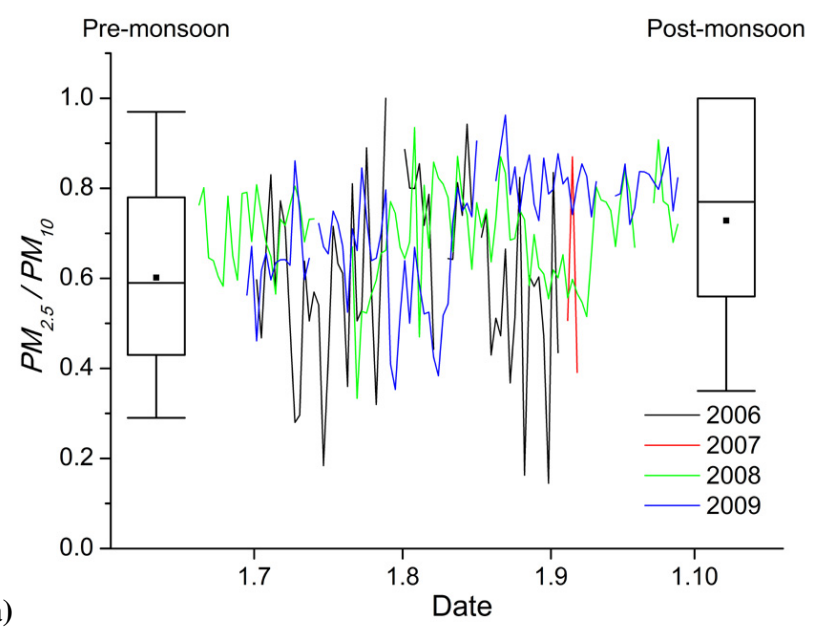

(a)

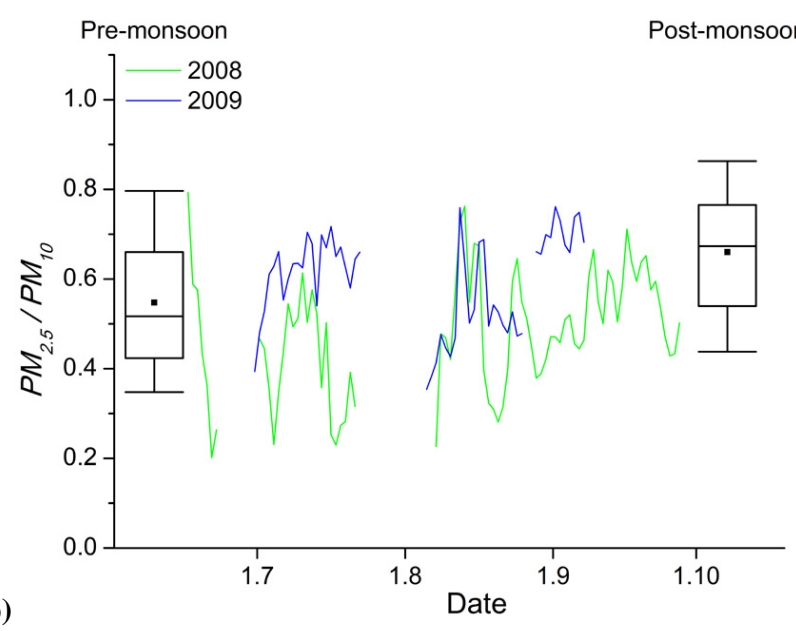

Fig. 9. Fraction of $\mathrm{PM}_{2.5}$ in $\mathrm{PM}_{10}$ mass. (a) Mukteshwar (b) Gual Pahari. Lines are $24 \mathrm{~h}$ running averages from the monsoon season, box plots denote to the pre- and post-monsoon seasonal values of $10 \%$-ile, $25 \%$-ile, median (line), average (dot), $75 \%$-ile, and $90 \%$ ile.

The BCe concentrations in Mukteshwar and Gual Pahari may not be directly comparable, as BCe in Mukteshwar was measured from a $\mathrm{PM}_{2.5}$ inlet and in Gual Pahari from a $\mathrm{PM}_{10}$ inlet. While typically around $90 \%$ of the BCe mass is accounted in $\mathrm{PM}_{2.5}$ (Putaud et al., 2004), we cannot rule out the possibility that Gual Pahari would be susceptible for primary soot from e.g. incomplete combustion. In fact, this is supported by the observed high BCe fraction in Gual Pahari.

\subsection{High concentration episodes during the monsoon}

As case studies, we characterize the peak concentrations during the monsoon season and pinpoint possible sources related to them.

As already reported in the literature (Dey and Tripathi, 2008; Gautam et al., 2009, 2011; Ram et al., 2008, 2010), mineral dust events are frequent in the Indo Gangetic Plains
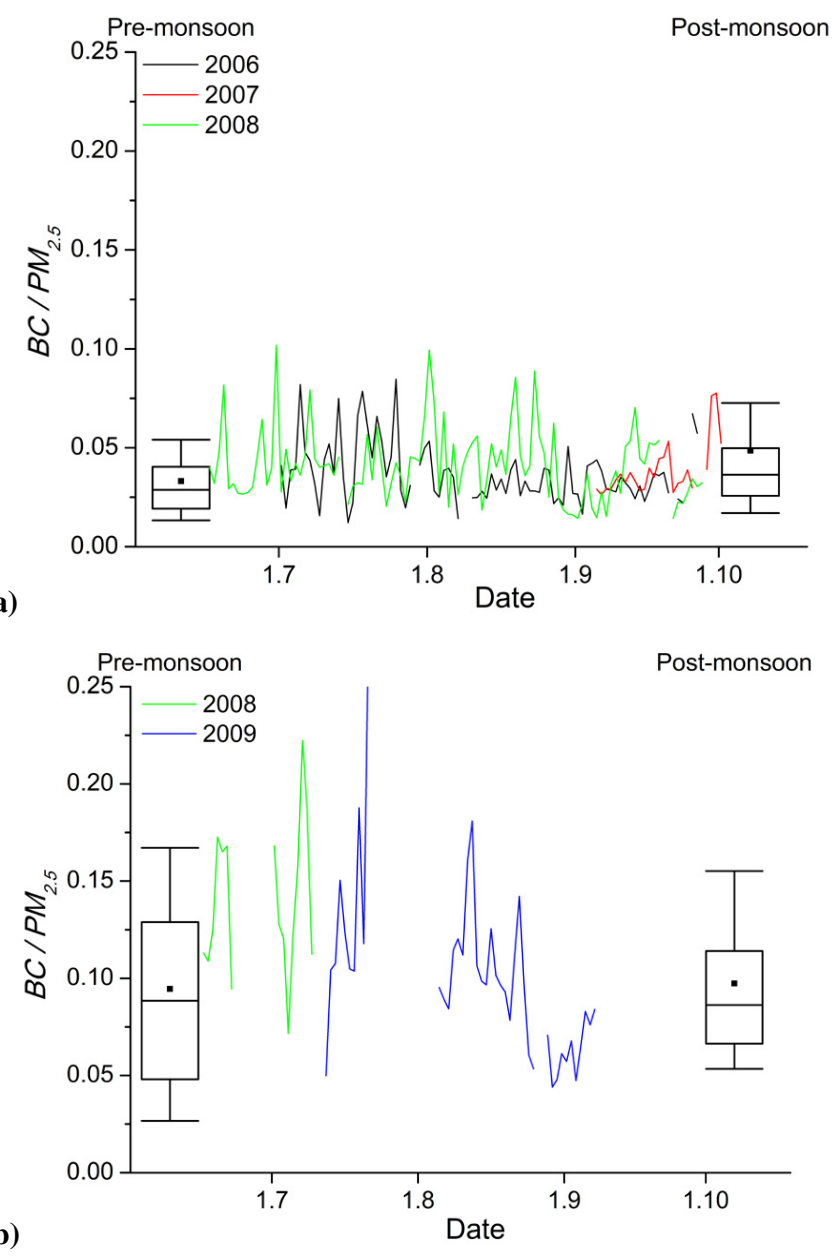

Fig. 10. Fraction of equivalent black carbon (BCe) in $\mathrm{PM}_{2.5}$ mass. (a) Mukteshwar (b) Gual Pahari. Lines are $24 \mathrm{~h}$ running averages from the monsoon season, box plots denote to the pre- and postmonsoon seasonal values of $10 \%$-ile, $25 \%$-ile, median (line), average (dot), $75 \%$-ile, and $90 \%$-ile.

and occur in the Himalayan foothills, too, during the premonsoon season. The dominance of mineral dust in the high concentration events observed here is backed by information that most of the events had a $\mathrm{PM}_{2.5} / \mathrm{PM}_{10}$ ratio of about $0.1-$ 0.2 indicating a dominant coarse mode from primary particles (Fig. 11). At Gual Pahari, a high mode at around $4 \mu \mathrm{m}$ was seen simultaneously in the volume size distribution data (Hyvärinen et al., 2011). We further analyzed trajectories arriving at the time of the high concentration episodes. In Mukteshwar, these trajectories originated from two directions: the Thar Desert in the Southwest, and from the Himalayan region, east of the station (Fig. 12a and b). In Gual Pahari, the episodes with the $\mathrm{PM}_{2.5} / \mathrm{PM}_{10}$ between $0.1-0.2$ also originated from Thar Desert (Fig. 12c). It is notable that the highest $\mathrm{PM}_{10}$ concentrations during the monsoon season were observed in Mukteshwar, not Gual Pahari. While the actual reason for this is unknown, it is likely related to weather 
Table 4. Percentage of days exceeding the $24 \mathrm{~h} \mathrm{PM}_{2.5}$ guideline value set either by the Indian National Air Pollution Board or the WHO. In addition the campaign averages are shown in ambient concentrations with and without the monsoon season.

\begin{tabular}{|c|c|c|c|c|c|c|}
\hline \multirow{2}{*}{$\begin{array}{l}\text { Standard } 24 \mathrm{~h} \mid \text { annual } \\
\begin{array}{l}\text { Days } \\
\text { exceeding }\end{array}\end{array}$} & \multicolumn{2}{|c|}{ National $60 \mu \mathrm{g} \mathrm{m}^{-3}$} & \multicolumn{2}{|c|}{ WHO $25 \mu \mathrm{g} \mathrm{m}^{-3}$} & \multirow{2}{*}{$\begin{array}{l}\text { National } 40 \mu \mathrm{g} \mathrm{m}^{-3} \\
\text { Average } \\
\text { all time }\end{array}$} & \multirow{2}{*}{$\begin{array}{l}\text { WHO } 10 \mu \mathrm{g} \mathrm{m}^{-3} \\
\begin{array}{l}\text { Average } \\
\text { no monsoon }\end{array}\end{array}$} \\
\hline & $\begin{array}{r}\text { Outside } \\
\text { monsoon }\end{array}$ & $\begin{array}{r}\text { During } \\
\text { monsoon }\end{array}$ & $\begin{array}{l}\text { Outside } \\
\text { monsoon }\end{array}$ & $\begin{array}{r}\text { During } \\
\text { monsoon }\end{array}$ & & \\
\hline Mukteshwar & $10 \%$ & $0 \%$ & $51 \%$ & $26 \%$ & $28 \mu \mathrm{g} \mathrm{m}^{-3}$ & $31 \mu \mathrm{g} \mathrm{m}^{-3}$ \\
\hline Gual Pahari & $87 \%$ & $13 \%$ & $99 \%$ & $81 \%$ & $111 \mu \mathrm{g} \mathrm{m}^{-3}$ & $133 \mu \mathrm{g} \mathrm{m}^{-3}$ \\
\hline
\end{tabular}

Table 5. Percentage of days exceeding the $24 \mathrm{~h} \mathrm{PM}_{10}$ guideline value set either by the National Air Pollution Board or the WHO. In addition the campaign averages are shown in ambient concentrations with and without the monsoon season.

\begin{tabular}{|c|c|c|c|c|c|c|}
\hline \multirow{2}{*}{$\begin{array}{l}\text { Standard } 24 \mathrm{~h} \mid \text { annual } \\
\text { Days } \\
\text { exceeding }\end{array}$} & \multicolumn{2}{|c|}{ National $100 \mu \mathrm{g} \mathrm{m}^{-3}$} & \multicolumn{2}{|c|}{ WHO $50 \mu \mathrm{g} \mathrm{m}^{-3}$} & \multirow{2}{*}{$\begin{array}{l}\text { National } 60 \mu \mathrm{g} \mathrm{m}^{-3} \\
\text { Average } \\
\text { all time }\end{array}$} & \multirow{2}{*}{$\begin{array}{l}\text { WHO } 20 \mu \mathrm{g} \mathrm{m}^{-3} \\
\text { Average } \\
\text { no monsoon }\end{array}$} \\
\hline & $\begin{array}{l}\text { Outside } \\
\text { monsoon }\end{array}$ & $\begin{array}{r}\text { During } \\
\text { monsoon }\end{array}$ & $\begin{array}{l}\text { Outside } \\
\text { monsoon }\end{array}$ & $\begin{array}{r}\text { During } \\
\text { monsoon }\end{array}$ & & \\
\hline Mukteshwar & $11 \%$ & $2 \%$ & $44 \%$ & $19 \%$ & $45 \mu \mathrm{g} \mathrm{m}^{-3}$ & $51 \mu \mathrm{g} \mathrm{m}^{-3}$ \\
\hline Gual Pahari & $94 \%$ & $29 \%$ & $99 \%$ & $77 \%$ & $188 \mu \mathrm{g} \mathrm{m}^{-3}$ & $227 \mu \mathrm{g} \mathrm{m}^{-3}$ \\
\hline
\end{tabular}

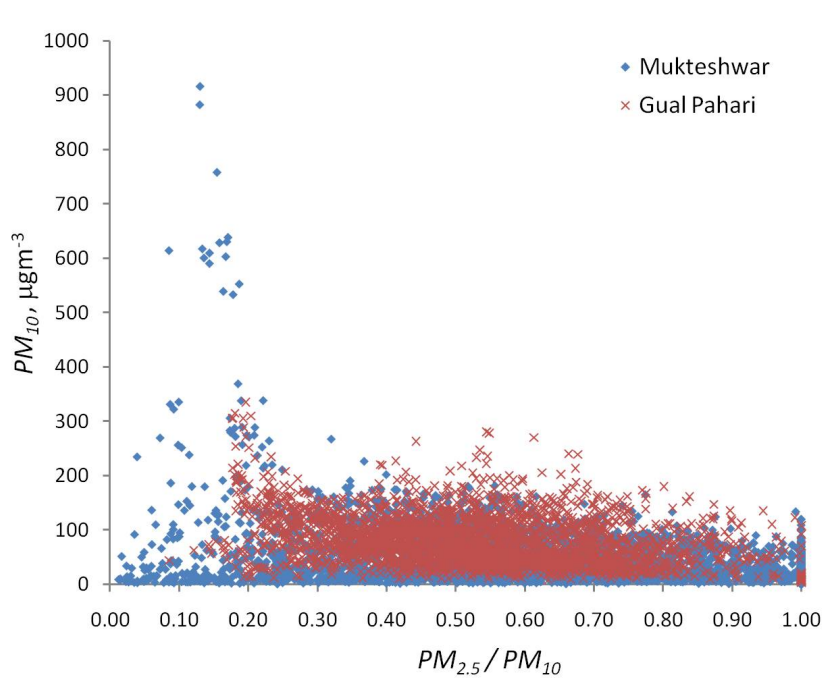

Fig. 11. $\mathrm{PM}_{10}$ mass during the monsoon season as a function of the $\mathrm{PM}_{2.5} / \mathrm{PM}_{10}$ ratio. Concentrations are in STP conditions.

and rain patterns during the transport from the source area to the station. Another point worth mentioning is that the dust events occurred mostly before August. The monsoon rains typically begin in the Thar region in August, after which the source strength of re-suspended dust naturally decreases. In Gual Pahari, in addition to dust events, also events with $\mathrm{PM}_{2.5} / \mathrm{PM}_{10}$ ratio between 0.4 and 0.7 occurred (see Fig. 11 and Fig. 12d). These winding air masses advanced slowly, and they all surpassed New Delhi. The higher fraction of fine particles implies that particles were likely from anthropogenic emissions. Re-suspended road dust and construction activities in nearby areas were also likely to contribute to the coarse fraction of these events.

\subsection{Comparison to health regulation standards}

We compared the PM concentrations against health regulation standards set by two quarters: the Indian Pollution Control Board and the World Health Organization. The $24 \mathrm{~h}$ and annual guidelines for $\mathrm{PM}_{2.5}$ and $\mathrm{PM}_{10}$ differ somewhat depending on the governing body. In Mukteshwar, both $\mathrm{PM}_{2.5}$ and $\mathrm{PM}_{10}$ concentrations typically stay below the National $24 \mathrm{~h}$ air quality standards, and for $\mathrm{PM}_{2.5}$ during monsoon season, no days exceeding this standard was found (Tables 4 and 5). However, the $24 \mathrm{~h}$ guidelines set by the WHO were not so easy to meet, which illustrates that even in this remote site, aerosols would have adverse health effects. In Gual Pahari, the situation was more alarming. The $24 \mathrm{~h}$ concentrations were below the National standards only really during the monsoon season, and even then the guidelines set by the WHO were exceeded on most days.

We also analyzed the transition times in respect to $\mathrm{PM}_{2.5}$ health regulation levels. In Mukteshwar, the transition times were short ( 2 to 10 days onset; 3 to 12 days withdrawal). The WHO limit of $25 \mu \mathrm{g} \mathrm{m}^{-3}$ was exceeded in $78 \%$ of the days during the pre-monsoon, $26 \%$ during the monsoon and $39 \%$ during the post-monsoon. The Indian National limits we exceeded in $23 \%$ of the days in the pre-monsoon, $0 \%$ of the days in the monsoon, and $13 \%$ of the days in the postmonsoon season. It is difficult to say anything definite about the transition periods from the health regulation perspective due to the short transition times. It can be observed, however, that directly after the onset transition period consecutive days 

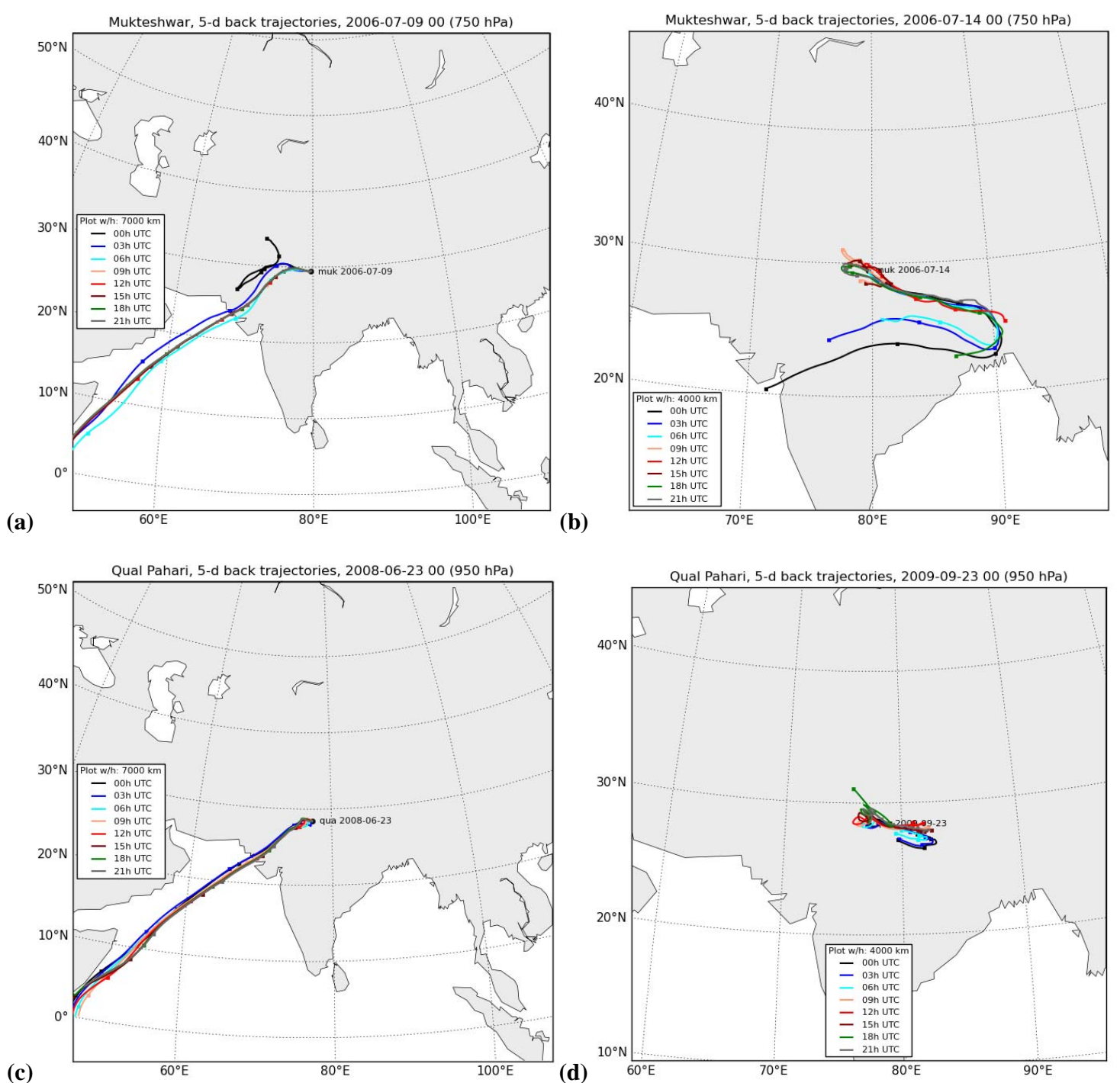

Fig. 12. 5-day calculated backtrack trajectories from example high concentration episodes during monsoon in Gual Pahari and Mukteshwar. (a, c) Mineral dust from the Thar desert. (b) Mineral dust from the Himalayan region. (d) Anthropogenic emissions from local sources and New Delhi.

exceeding the Indian National limit values were rare, while before the transition, the $24 \mathrm{~h}$ limit values could be exceeded in more than 7 days in a row. A similar finding was made for the withdrawal transition in Mukteshwar.

In Gual Pahari, the transition times were longer (23 to 29 days onset; 17 to 31 days withdrawal). The WHO $24 \mathrm{~h}$ PM$_{2.5}$ limit was exceeded with only occasional exceptions throughout the year. The Indian National limit of $60 \mu \mathrm{g} \mathrm{m} \mathrm{m}^{-3}$ was exceeded in $70 \%$ of the days during the pre-monsoon, $13 \%$ during the monsoon and $90 \%$ during the post-monsoon. At the beginning of the onset transition period, the fraction of days exceeding the Indian National limit per week was between 60 to $100 \%$. During the transition period, this number decreased steadily, and after the onset transition, only rare exceedings were observed. The withdrawal transition was very similar: fraction of days exceeding the limit value was between 0 and $50 \%$ at the beginning of the transition, and at the end of the transition, nearly every day exceeded the limit value.

Finally, we looked to find how much the monsoon season lowered the long term concentrations. While the lowered concentrations brought breathing space temporarily, they did not affect the long term exposure that much. During our measurements in Mukteshwar, the long term ambient $\mathrm{PM}_{2.5}$ average was $27.9 \mu \mathrm{g} \mathrm{m}^{-3}$. Without the rainy season, this number would have been $31.3 \mu \mathrm{g} \mathrm{m}^{-3}$. In Gual Pahari, the long term ambient $\mathrm{PM}_{2.5}$ average was $111.3 \mu \mathrm{g} \mathrm{m}^{-3}$, and without the rainy season it would have been $132.6 \mu \mathrm{g} \mathrm{m}^{-3}$ (Table 4). Similar results were found for $\mathrm{PM}_{10}$ (Table 5). In Mukteshwar, the long term average was below the National annual 
air quality standards, but still over the annual WHO guidelines. In Gual Pahari, the annual standards were exceeded alarmingly.

\section{Conclusions}

A 4-yr data set from Mukteshwar, the Indian Himalayas, and a 2-yr data set from Gual Pahari, Indo-Gangetic plains were utilized to study the effects of monsoon on atmospheric particulate matter and equivalent black carbon. We observed that the average monsoon aerosol concentrations were decreased by $55-70 \%$ compared to the pre-monsoon averages at both stations, deceasing as a function of the total local rainfall during the monsoon season. During the monsoon season in Mukteshwar, both $\mathrm{PM}_{2.5}$ and $\mathrm{PM}_{10}$ concentrations were almost always below the Indian National air quality standards. Also the concentrations in Gual Pahari were more often than not under the National air quality levels during the monsoon season. However, the guidelines given by the WHO were more difficult to meet. The monsoon season reduced the long term exposure to both $\mathrm{PM}_{2.5}$ and $\mathrm{PM}_{10}$ by about $10 \%$ in Mukteshwar and by about $15 \%$ in Gual Pahari. In Mukteshwar the reduction was less, because low concentrations were met also during the post-monsoon and winter.

Both the onset and withdrawal transitions occurred faster in Mukteshwar than in Gual Pahari, being typically less than 10 days. Transition periods in Gual Pahari took between 17 and 31 days. This indicates that the aerosol decrease and increase processes were driven differently at the two locations. A probable reason is the altitude difference at the two stations, with Mukteshwar being in the free troposphere most of the time. A higher altitude and the mountain terrain increased the precipitation in the beginning of the monsoon in Mukteshwar, leading to an effective washout. On the other hand, the post-monsoon season in Mukteshwar was represented by low concentrations, and aerosol characteristics were close to those during the monsoon season. The fact that the onset transitions were similar during 2008 and 2009 in Gual Pahari despite the different rain accumulation development indicates that the initiation of the aerosol decrease was a large scale phenomenon. However, it's interesting that at the end, the monsoon time decrease in aerosol concentrations could be estimated from the local rain amounts only.

In addition to loss processes, aerosol concentrations during the early monsoon were found to be affected by primary emissions, most likely dust events from the Thar Desert. This resulted in lowered $\mathrm{PM}_{2.5} / \mathrm{PM}_{10}$ fractions at both stations. In Mukteshwar, additional dust contribution came from the arid regions on the southern slopes of Himalayas. A high fraction of PM mass consisted of BCe in Gual Pahari in the monsoon season, suggesting strong anthropogenic influence from $\mathrm{New}$ Delhi.
Acknowledgements. Measurements in the Gual Pahari station were funded by the The European Integrated project on Aerosol Cloud Climate and Air Quality Interactions, EUCAARI. The Mukteshwar measurements were funded by The Ministry of Foreign Affairs of Finland: "Particulate pollution and the Indian Brown Cloud associated with it" - project. Timo Anttila and Ari Halm are acknowledged for technical assistance and Juha Hatakka for trajectory calculations. TERIs staff is acknowledged for their valuable routine maintenance of instruments in Gual Pahari and Mukteshwar stations.

Edited by: A. Wiedensohler

\section{References}

Bollasina, M., Nigam, S., and Lau, K.-M.: Absorbing Aerosols and Summer Monsoon Evolution over South Asia: An Observational Portrayal, J. Climate, 21, 3221-3239, 2008.

Bohren, C. F. and Huffman, D. R.: Absorption and scattering of light by small particles, John Wiley and Sons, New York, 530 pp., 1983.

Dey, S. and Tripathi, S. N.: Aerosol direct radiative effects over Kanpur in the Indo-Gangetic basin, northern India: Long-term (2001-2005) observations and implications to regional climate, J. Geophys. Res., 113, D04212, doi:10.1029/2007JD009029, 2008.

Gautam, R., Hsu, N. C., Lau, K.-M., and Kafatos, M.: Aerosol and rainfall variability over the Indian monsoon region: distributions, trends and coupling, Ann. Geophys., 27, 3691-3703, doi:10.5194/angeo-27-3691-2009, 2009.

Gautam, R., Hsu, N. C., Tsay, S. C., Lau, K. M., Holben, B., Bell, S., Smirnov, A., Li, C., Hansell, R., Ji, Q., Payra, S., Aryal, D., Kayastha, R., and Kim, K. M.: Accumulation of aerosols over the Indo-Gangetic plains and southern slopes of the Himalayas: distribution, properties and radiative effects during the 2009 pre-monsoon Season, Atmos. Chem. Phys. Discuss., 11, 15697-15743, doi:10.5194/acpd-11-15697-2011, 2011.

Gurjar, B. R., Jain, A., Sharma, A., Agarwal, A., Gupta, P., Nagpure, A. S., and Lelieveld, J.: Human health risks in megacities due to air pollution, Atmos. Environ., 44(36), 4606-4613, doi:10.1016/j.atmosenv.2010.08.011, 2010.

Hyvärinen, A.-P, Lihavainen, H., Komppula, M., Sharma, V. P. Kerminen, V.-M., Panwar, T. S., and Viisanen, Y.: Continuous measurements of optical properties of atmospheric aerosols in Mukteshwar, Northern India, J. Geophys. Res., 114, D08207, doi:10.1029/2008JD011489, 2009.

Hyvärinen, A.-P., Lihavainen, H., Komppula, M., Panwar, T. S., Sharma, V. P., Hooda, R. K., and Viisanen, Y.: Aerosol measurements at the Gual Pahari EUCAARI station: preliminary results from in-situ measurements, Atmos. Chem. Phys., 10, 72417252, doi:10.5194/acp-10-7241-2010, 2010.

Hyvärinen, A.-P., Raatikainen, T., Komppula, M., Mielonen, T., Sundström, A.-M., Brus, D., Panwar, T. S., Hooda, R. K., Sharma, V. P., de Leeuw, G., and Lihavainen, H.: Effect of the summer monsoon on aerosols at two measurement stations in Northern India - Part 2: Physical and optical properties, Atmos. Chem. Phys., 11, 8283-8294, doi:10.5194/acp-11-82832011, 2011. 
Komppula, M., Lihavainen, H., Hyvärinen, A.-P., Kerminen, V.-M., Panwar, T. S., Sharma, V. P., and Viisanen, Y.: Physical properties of aerosol particles at a Himalayan background site in India, J. Geophys. Res., 114, D12202, doi:10.1029/2008JD011007, 2009.

Lau, K. M. and Kim, K.-M.: Observational relationship between aerosol and Asian rainfall and circulation, Geophys. Res. Lett., 33, L21810, doi:10.1029/2006GL027546, 2006.

Lelieveld, J., Crutzen, P. J., Ramanathan, V., Andreae, M. O., Brenninkmeijer, C. A. M., Campos, T., Cass, G. R., Dickerson, R. R., Fischer, H., de Gouw, J. A., Hansel, A., Jefferson, A., Kley, D., de Laat, A. T. J., Lal, S., Lawrence, M. G., Lobert, J. M., MayolBracero, O. L., Mitra, A. P., Novakov, T., Oltmans, S. J., Prather, K. A., Reiner, T., Rodhe, H., Scheeren, H. A., Sikka D., and Williams, J.: The Indian Ocean Experiment: Widespread air pollution from South and Southeast Asia, Science 291, 1031-1036, 2001.

Nakajima, T., Yoon, S.-C., Ramanathan, V., Shi, G.-Y., Takemura, T., Higurashi, A., Takamura, T., Aoki, K., Sohn, B.-J., Kim, S.-W., Tsuruta, H., Sugimoto, N., Shimizu, A. Tanimoto, H., Sawa, Y., Lin, N.-H., Lee, C.-T., Goto, D., and Schutgens, N.: Overview of the atmospheric Brown Cloud East Asian Regional Experiment 2005 and a study of the aerosol direct radiative forcing in east Asia, J. Geophys. Res., 112, D24S91, doi:10.1029/2007JD009009, 2007.

Meehl, G. A., Arblaster, J. M., and Collins, W. D.: Effects of Black Carbon Aerosols on the Indian Monsoon, J. Climate, 21, 28692882, 2008.

Panwar, T. S., Hooda, R. K., Lihavainen, H., Hyvrinen, A.-P., Sharma, V. P., and Viisanen, Y.: Atmospheric aerosols at a regional background Himalayan site - Mukteshwar, India, Environ. Monit. Assess., in review, 2011.

Putaud J.-P., Raes F., Van Dingenen R., Brüggemann E., Facchini M.-C., Decesari S., Fuzzi S., Gehrig R., Hüglin C., Laj P., Lorbeer G., Maenhaut W., Mihalopoulos N., Müller K., Querol X., Rodriguez S., Schneider J., Spindler G., ten Brink H., Tørseth K., and Wiedensohler A.: A European aerosol phenomenology 2: chemical characteristics of particulate matter at kerbside, urban, rural and background sites in Europe, Atmos. Environ., 38, 2579-2595, 2004.
Raatikainen, T., Hyvärinen, A.-P., Hatakka, J., Panwar, T. S., Hooda, R. K., Sharma, V. P., and Lihavainen, H.: Comparison of aerosol properties from the Indian Himalayas and the Indo-Gangetic plains, Atmos. Chem. Phys. Discuss., 11, 11417 11453, doi:10.5194/acpd-11-11417-2011, 2011.

Ram, K., Sarin, M. M., and Hedge, P.: Atmospheric abundances of primary and secondary carbonaceous species at two high-altitude sites in India : Sources and temporal variability, Atmos. Environ., 42(28), 6785-6796, 2008.

Ram, K., Sarin, M. M., and Tripathi, S. N.: A 1 year record of carbonaceous aerosols from an urban site in the Indo-Gangetic Plain: Characterization, sources, and temporal variability, J. Geophys. Res., 115, D24313, doi:10.1029/2010JD014188, 2010.

Ramanathan, V., Li, F., Ramana, M. V., Praveen, P. S., Kim, D., Corrigan, C. E., Nguyen, H., Stone, E. A., Schauer, J. J., Carmichael, G. R., Adhikary, B., and Yoon, S. C.: Atmospheric brown clouds: Hemispherical and regional variations in longrange transport, absorption, and radiative forcing, J. Geophys. Res., 112, D22S21, doi:10.1029/2006JD008124, 2007.

Stohl, A., Wotawa, G., Seibert, P., and Kromp-Kolb, H.: Interpolation errors in wind fields as a function of spatial and temporal resolution and their impact on different types of kinematic trajectories, J. Appl. Meteorol., 34, 2149-2165, 1995.

Tyagi, A., Hatwar, H. R., and Pai, D. S., eds.: Monsoon 2008, A report, Government of India, India Meteorological Department, 2009.

Tyagi, A., Hatwar, H. R., and Pai, D. S. (Eds.): Monsoon 2009, A report, Government of India, India Meteorological Department, 2010. 